\title{
ARTIKELEN
}

\section{If it was shared on Facebook and Twitter, then it must be true. Een kwantitatief onderzoek naar de relatie tussen fake news en angst voor crimi- naliteit}

Birte Vandaele, Thom Snaphaan \& Wim Hardyns

\begin{abstract}
Media vormen een belangrijke informatiebron voor burgers over criminaliteit. Dit onderzoek toont aan dat mediaberichtgeving en angst voor criminaliteit niet losstaan van elkaar. Aangezien fakenewsberichten zich via (sociale) media verspreiden, rijst de vraag wat de relatie is tussen (de perceptie van) fake news en angst voor criminaliteit. Vooralsnog werd hieromtrent geen grootschalig en representatief onderzoek gevoerd. Deze studie baseert zich op een representatieve bevolkingsbevraging $(n=1566)$ uit 2019. Deze verkennende studie toont een kleine maar significante relatie tussen de gepercipieerde prevalentie van fake news en angst voor criminaliteit.
\end{abstract}

\section{$1 \quad$ Inleiding}

Sinds de Amerikaanse presidentsverkiezingen van 2016 is fake news alomtegenwoordig. Fakenewsberichten verschenen massaal in het voor- of nadeel van presidentskandidaten om kiezers te winnen. Door de snelle groei van het internet en de massamedia in de late twintigste eeuw en de opkomst van de sociale media in de 21ste eeuw is het fenomeen fake news buitengewoon groot geworden. Ondanks de recent verhoogde aandacht voor fake news, is het geen nieuw fenomeen. Er wordt aangenomen dat fake news even oud is als de nieuwsmedia zelf (Burkhardt, 2017). De verspreiding van fake news blijft ook niet zonder gevolgen. Fake news kan bijvoorbeeld schadelijk zijn voor de volksgezondheid (denk maar aan foutieve berichtgeving omtrent COVID-19-vaccinaties) en voor de democratische rechtsstaat (denk bijvoorbeeld aan het verspreiden van foutieve informatie over de overheid). Een actueel voorbeeld van fake news waren de WhatsApp- en Facebookberichten die werden verspreid met foutieve informatie over het coronavirus. De 'noodberichten' pretendeerden officiële informatie te zijn uit naam van de overheid, maar ze bevatten foutieve medische informatie en incorrecte tot zelfs gevaarlijke preventietips (Verheyden, 2020).

Voor de meeste burgers zijn media de belangrijkste informatiebron als het gaat over berichtgeving over criminaliteit. De vraag stelt zich of mensen zich (onnodig) onveiliger gaan voelen door (foutieve) mediaberichtgeving over criminaliteit. Uit verschillende wetenschappelijke studies is immers gebleken dat media en angst 
voor criminaliteit niet losstaan van elkaar (Pleysier, 2009). Ze kunnen op verschillende manieren een rol spelen in het versterken van onveiligheidsgevoelens (Elffers \& De Jong, 2004). Met deze bijdrage willen we nagaan wat de relatie is tussen fake news en angst voor criminaliteit. Grootschalig onderzoek hiernaar ontbreekt in de huidige wetenschappelijke literatuur.

\section{Fake news en angst voor criminaliteit}

Ondanks de alomtegenwoordigheid van de term fake news in het publieke discours, toont de wetenschappelijke literatuur aan dat fake news geen universele consistente definitie kent (Jaster \& Lanius, 2018). Definities belichten de aspecten, voorwaarden, eigenschappen en doelen telkens op een andere manier. Het staat ook vast dat mensen van nature niet makkelijk fake news van waarheidsgetrouwe informatie kunnen onderscheiden. Dit komt mede doordat fake news gewoonlijk inspeelt op individuele kwetsbaarheden, bijvoorbeeld wanneer een hele gemeenschap wordt gestigmatiseerd in de communicatie naar (de omgeving van) slachtoffers van criminaliteit. Daarnaast kan men niet zomaar besluiten dat personen die fake news delen of ermee geconfronteerd worden, hierdoor noodzakelijk zelf beïnvloed worden of het voor waarheid aannemen (Lazer et al., 2018) en kan het presenteren van correcte informatie reeds gevormde misvattingen zelfs versterken (Shu et al., 2017). De media zijn constant aanwezig in het dagelijks leven en informeren, net zoals ze ook foutief kunnen informeren (Heath \& Gilbert, 1996). Persoonlijke ervaringen en gebeurtenissen in de eigen leefomgeving zijn evenzeer een bron van informatie voor burgers wat betreft (de perceptie van) criminaliteit.

Angst voor criminaliteit is sinds de jaren zestig van de vorige eeuw uitgegroeid tot een belangrijke onderzoekslijn binnen de criminologie en victimologie. De afgelopen decennia is al heel wat inkt gevloeid en zijn al heel wat debatten gevoerd over verschillende aspecten van angst voor criminaliteit (Ditton \& Farrall, 2000; Hale, 1996; Pleysier, 2009; Vanderveen, 2006). Algemeen kunnen twee conceptualisaties van angst voor criminaliteit onderscheiden worden. De enge conceptualisatie heeft uitsluitend betrekking op de emotioneel-affectieve dimensie van angst voor criminaliteit en kan omschreven worden als de emotionele reactie die gepaard gaat met angst voor criminaliteit. De brede conceptualisatie voegt hier nog de cognitieve en gedragsmatig-expressieve dimensies aan toe. De cognitieve dimensie gaat vooraf aan de gedragsmatig-expressieve dimensie en houdt de risico-inschatting op slachtofferschap in die wordt gemaakt aan de hand van signalen en stimuli uit de omgeving. De gedragsmatig-expressieve dimensie kan gezien worden als de gedragsresultante op ervaren gevoelens van angst. Voorbeelden van de gedragsmatig-expressieve component zijn mijdgedrag en defensieve reacties (De Groof, 2006; Hardyns \& Pauwels, 2010; Hardyns et al., 2019b; Pleysier, 2009). In verband met de vele conceptualisaties en definities van angst voor criminaliteit is het relevant om te verwijzen naar de metafoor van Farrall en collega's (2009): fear of crime as a sponge. Ze wijzen hiermee op de vaststelling dat angst voor criminaliteit als een spons werkt die ook meer algemene angsten en andere emoties (anders dan die met betrekking tot criminaliteit) opneemt. Het is belangrijk om deze metafoor in 
acht te nemen bij het meten en analyseren van resultaten over angst voor criminaliteit.

Verschillende onderzoekers bestudeerden reeds de mogelijke relatie tussen de media en angst voor criminaliteit. Een van de eerste studies vond plaats in de jaren zeventig van vorige eeuw en werd uitgevoerd door Gerbner en Gross (1976), met de cultivatietheorie als achtergrond. Zij onderzochten de effecten van televisiegebruik op angst voor criminaliteit (Heath \& Gilbert, 1996). Verschillende onderzoekers uitten kritiek op de door hen gevonden relatie tussen televisiekijken en angst voor criminaliteit. Ze reanalyseerden de datasets en constateerden dat de effecten van televisiekijken veel complexer zijn dan werd gesteld. Analyses van nieuwe datasets toonden dit eveneens aan (Adriaenssen, 2016; Heath \& Gilbert, 1996; Hirsch, 1980, 1981; Hughes, 1980; Lee, 2007). Onderzoek suggereert dat mediaberichten een effect kunnen hebben op iemands angst voor criminaliteit als diegene zich kan identificeren met het slachtoffer, de context of het bredere beeld van de maatschappij (Pleysier, 2009). Chiricos en collega's (2000) constateerden bijvoorbeeld dat televisienieuws een groter effect heeft wanneer dit aansluit bij de eigen ervaringen of de eigen misdaadrealiteit van de respondenten.

Wat wel dient opgemerkt te worden, is dat in bepaalde studies samenhang en causaliteit met elkaar verward werden en de conclusies daarenboven vaak steunden op fragmentaire theorievorming rond de interactie tussen media en angst voor criminaliteit (Pleysier, 2009). Lembrechts (2007) stelt dat onderzoek naar de relatie tussen angst voor criminaliteit en media zeer complex is, en dat deze relatie best vanuit meerdere disciplines wordt onderzocht. De wederzijdse beïnvloeding tussen de media en het publiek, met elk hun eigen diversiteit, bevindt zich niet in een vacuum. De blootstelling en beïnvloeding zijn bovendien afhankelijk van de kenmerken van de mediavorm in kwestie, de karakteristieken van het publiek en de manier waarop ze gemeten worden (Chiricos et al., 1997; Heath \& Gilbert, 1997; Lane \& Meeker, 2003).

Over de relatie tussen blootstelling aan informatie over criminaliteit in de media en angst voor criminaliteit bestaat geen consensus. Näsi en collega's (2021) onderzochten naar de rol van traditionele media, sociale media en alternatieve informatiebronnen bij angst voor geweld. Zij constateerden dat angst voor straatgeweld wordt beïnvloed door het actieve gebruik van alle typen media. Zij vonden geen samenhang tussen mijdgedrag en mediagebruikpatronen, maar wel een samenhang tussen een meer algemene belangstelling voor nieuws over geweld en mijdgedrag, samen met daadwerkelijke negatieve ervaringen. Ditton en collega's (2004) voerden een kwalitatief onderzoek uit naar de relatie tussen media, criminaliteit en angst voor criminaliteit. Zij constateerden eveneens dat het niet zozeer de blootstelling, maar eerder de interpretatie van de media-inhoud door en voor de burger relevant is bij angst voor criminaliteit.

Grootschalig onderzoek naar de mogelijke relatie tussen fake news en angst voor criminaliteit ontbreekt in de huidige wetenschappelijke literatuur. Op macroniveau kan de bedenking worden gemaakt dat er geen logisch verband bestaat tussen fake news en angst voor criminaliteit, aangezien de verspreiding van fake news een vlucht nam met de komst van sociale media en de algemene trend van angst voor criminaliteit laat al jaren een dalende lijn zien (Centraal Bureau voor de Sta- 
tistiek, 2020). Macro- en microverklaringen mogen echter niet verward worden. De relatie tussen fake news en angst voor criminaliteit is op individueel niveau nog maar zelden onderzocht. Enkel in de studie van Hendriks (2019) stond deze specifieke relatie centraal. De studie toonde aan dat self-efficacy (waaronder het ingeschatte vermogen om fake news te herkennen wordt verstaan) en perceived realism (waaronder de mate waarin een fakenewsbericht als echt wordt ervaren wordt verstaan) een invloed hadden op de relatie tussen fake news en angst voor criminaliteit. In deze studie werd echter een convenience sample gehanteerd en dus kan men de resultaten niet zomaar veralgemenen naar de populatie.

Er is bijgevolg nood aan grootschalig en representatief onderzoek naar de relatie tussen fake news en angst voor criminaliteit. Met deze studie trachten we hiertoe bij te dragen door na te gaan wat de relatie is tussen de gepercipieerde prevalentie van fake news en angst voor criminaliteit. We focussen ons daarbij op de gedragsmatig-expressieve dimensie van angst voor criminaliteit, met name mijdgedrag; waarbij wordt gecontroleerd voor andere relevante variabelen.

\section{Conceptueel model van deze studie}

Angst voor criminaliteit wordt beïnvloed door heel wat verschillende factoren die eigen zijn aan het individu of aan diens omgeving. In deze studie maken we een onderscheid tussen factoren die kunnen beschouwd worden als 'gepercipieerde (on)veiligheid' en factoren die kunnen beschouwd worden als 'individuele kwetsbaarheid'.

Slachtofferschap en gepercipieerde overlast zijn elementen die een rol spelen in de gepercipieerde (on)veiligheid. Verschillende studies hebben een relatie kunnen aantonen tussen voorgaand slachtofferschap en angst voor criminaliteit (bijv. Cossman \& Rader, 2011; Ferguson \& Mindel, 2007; Gainey et al., 2011; Pleysier, 2009; Taylor \& Hale, 1986; Wyant, 2008). Deze relatie is echter complex en niet-monocausaal. Ten eerste omwille van de verschillen in de subjectieve betekenis die het slachtoffer aan de gebeurtenis toekent. Ook spelen heel wat andere factoren een rol, zoals individuele eigenschappen, buurtkenmerken, het soort misdrijf en de vorm van het slachtofferschap, namelijk direct of indirect (Pleysier, 2009). Daarnaast wordt in bepaalde studies gesteld dat vrouwen en ouderen meer angst voor criminaliteit hebben, terwijl zij objectief gezien minder kans maken om slachtoffer te worden. Deze vaststelling wordt ook wel de fear-victimization paradox genoemd (Cossman \& Rader, 2011; Ferguson \& Mindel, 2007; Pleysier, 2009; Taylor \& Hale, 1986). Met gepercipieerde overlast wordt de ervaren fysieke en sociale overlast in de woonbuurt bedoeld. Studies hebben aangetoond dat de gepercipieerde overlast sterk positief geassocieerd kan worden met angst voor criminaliteit en zo ook een groot deel van iemands angst voor criminaliteit kan verklaren (Gainey et al., 2011; Hardyns \& Pauwels, 2014; Pleysier, 2009; Wyant, 2008).

Sociaal kapitaal zien we in deze studie als een indicator van individuele kwetsbaarheid en verwijst onder andere naar het sociale netwerk waarop iemand kan teruggevallen bij problemen of moeilijkheden. Verschillende studies hebben aangetoond dat sociaal kapitaal gelinkt kan worden aan angst voor criminaliteit (bijv. Ferguson \& Mindel, 2007; Gainey et al., 2011; Hardyns et al., 2019a). Individueel sociaal 
kapitaal zorgt voor meer steun, interactie, hulp en minder gevoelens van eenzaamheid, en helpt op die manier om angst voor criminaliteit tegen te gaan of te doen afnemen. Iemands sociale kapitaal wordt daarnaast ook beïnvloed door socio-demografische en -economische factoren, en buurtkenmerken (Pleysier, 2009). Die socio-demografische en -economische kenmerken zijn op hun beurt ook indicatoren van individuele kwetsbaarheid en spelen dus ook een rol wanneer we kijken naar angst voor criminaliteit. We hebben het dan bijvoorbeeld over iemands geslacht, leeftijd, opleidingsniveau, burgerlijke staat en inkomen (Cossman \& Rader, 2011; Gainey et al., 2011; Pleysier, 2009; Wyant, 2008).

In figuur 1 wordt een overzicht gepresenteerd van de individuele factoren die iemands angst voor criminaliteit kunnen bepalen. We hebben daarbij in het bijzonder aandacht voor de mogelijke relatie tussen media en angst voor criminaliteit, waarbij nagegaan zal worden of de eigen inschatting van de mate van het voorkomen van fake news op enerzijds traditionele nieuwsmedia en anderzijds sociale media een positief effect heeft op angst voor criminaliteit.

\section{Figuur 1 Conceptueel model met angst voor criminaliteit als afhankelijke variabele}

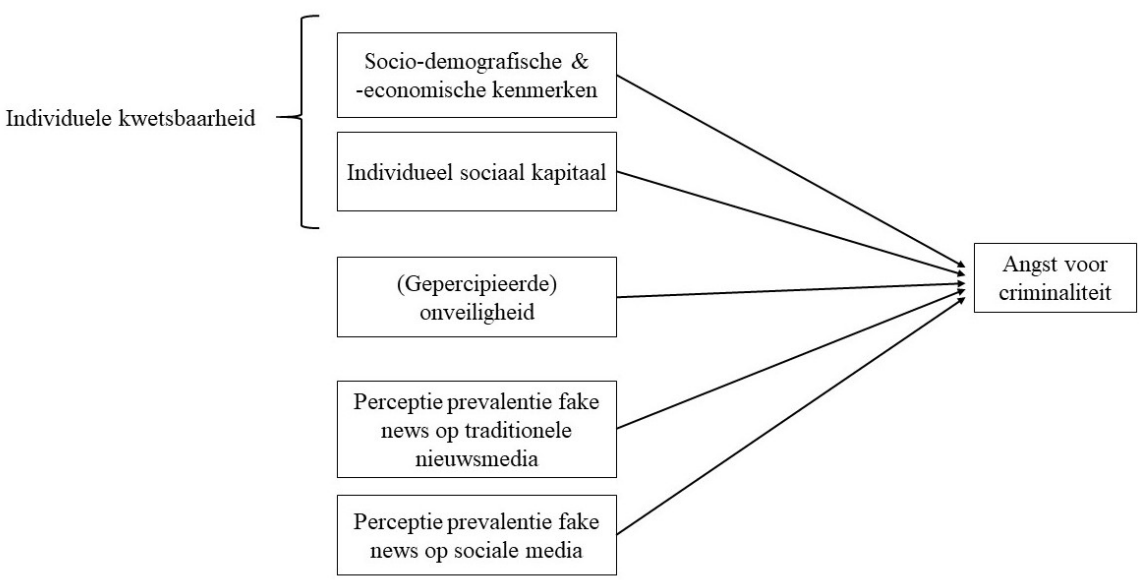

Traditionele nieuwsmedia hebben zo goed als allemaal sociale-media-accounts en delen hun nieuwsberichten ook via die weg. De sociale media zijn niet meer weg te denken uit het dagelijks leven en worden door heel wat mensen als primaire informatiebron gebruikt. De sociale media zijn vaak gratis, snel en het is eenvoudig om nieuws te delen en te becommentariëren (Shu et al., 2017). Voorgaand onderzoek toonde aan dat een hoge mate van sociale-mediaconsumptie significant gerelateerd is aan meer angst voor criminaliteit en deze relatie varieert afhankelijk van de eigen veiligheidspercepties (Intravia et al., 2017). Om deze redenen worden kenmerken van online gedrag en kennis mee opgenomen om na te gaan of deze een positief effect hebben op de gepercipieerde prevalentie van fake news (zie figuur 2 en 3). Daarnaast wordt ook nagegaan of de gepercipieerde prevalentie van fake news op het ene platform (traditionele media of sociale media) een effect heeft op de 
gepercipieerde prevalentie van fake news op het andere platform (vice versa), omdat traditionele nieuwsmedia en sociale-mediaplatformen dus niet volledig los van elkaar bestaan (zie figuur 2 en 3). De socio-demografische en -economische kenmerken worden daarbij als controlevariabelen opgenomen.

Figuur 2 Conceptueel model met de gepercipieerde prevalentie van fake news op traditionele media als afhankelijke variabele

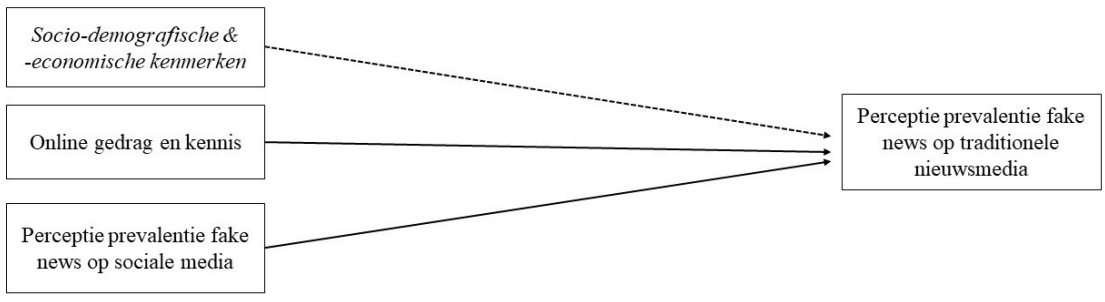

Figuur 3 Conceptueel model met de gepercipieerde prevalentie van fake news op sociale media als afhankelijke variabele

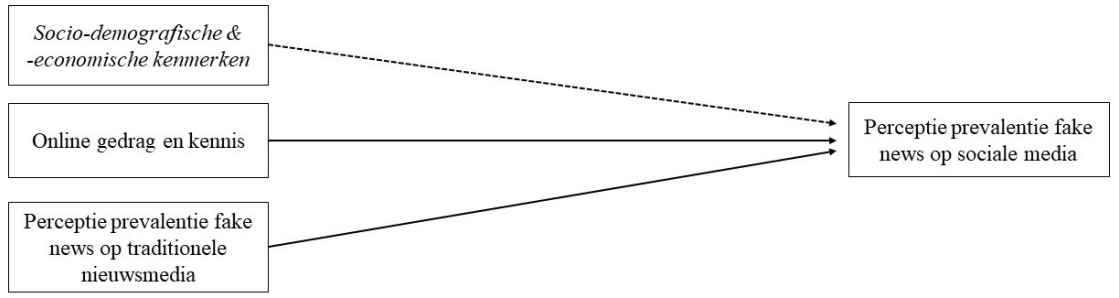

\section{Data en methoden}

In deze paragraaf wordt de representatieve bevolkingsbevraging waarop dit onderzoek gebaseerd is beknopt beschreven. Verder wordt de operationalisering van de variabelen toegelicht. Ten slotte komt de analytische strategie aan bod.

\subsection{De steekproef}

De data werden verkregen via een representatieve bevolkingsbevraging in een Belgische grootstad in 2019. De steekproef is samengesteld op basis van het bevolkingsregister. Buurtbewoners kwamen in aanmerking als ze voldeden aan bepaalde inclusiecriteria: ouder zijn dan 16 jaar, voldoende kennis hebben van het Nederlands om het afnemen van de vragenlijst mogelijk te maken, bereid zijn om vrijwillig deel te nemen aan de studie, woonachtig zijn in een van de vijftig buurten die werden geselecteerd en niet wonen in een residentiële setting. De steekproef is gestratificeerd naar geslacht, leeftijd en nationaliteit. Het oorspronkelijke doel was om 1880 respondenten te bevragen. Na datacleaning bleven 1566 valide responses over. 
In totaal was $48,9 \%$ van de respondenten mannelijk en $51,1 \%$ vrouwelijk. Allen zijn tussen de 18 en 94 jaar oud; de gemiddelde leeftijd is 48 jaar. Daarnaast werd $88,6 \%$ als Belg geboren en $11,4 \%$ niet. In totaal behaalde $59,3 \%$ van de respondenten als hoogste diploma een hogeschool- of universitair diploma, 29,9\% een middelbareschooldiploma en 7,3\% maakte de lagere school af. 3,4\% gaf aan geen diploma behaald te hebben.

\subsection{Operationalisering van de variabelen}

De beschrijvende gegevens van de variabelen en de specificering van de categorieën zijn terug te vinden in tabel 4 tot en met 13 in de appendix (te vinden na de literatuurlijst). De kenmerken van individuele kwetsbaarheid bestaan uit socio-demografische kenmerken, socio-economische kenmerken en het individueel sociaal kapitaal. De socio-demografische kenmerken bestaan uit vier variabelen. Nationaliteit is een dichotome variabele die verwijst naar het al dan niet geboren zijn met de Belgische nationaliteit en werd gecodeerd als nul voor Belg en één voor nietBelg. Geslacht is een dichotome variabele die als één werd gecodeerd voor vrouwen en nul voor mannen. De variabele alleenstaand werd geconstrueerd aan de hand van de variabele over het al dan niet hebben van een romantische relatie. Alleenstaand werd gecodeerd als één en het hebben van een romantische relatie als nul. De variabele leeftijd werd opgedeeld in zes categorieën: 18-24 jaar, 25-34 jaar, 35-44 jaar, 45-54 jaar, 55-64 jaar en 65 jaar of ouder. De socio-economische kenmerken bestaan uit twee variabelen. Het opleidingsniveau werd gemeten aan de hand van een vierpuntenschaal: geen diploma, diploma lager onderwijs of lager secundair, diploma secundair onderwijs en diploma hoger onderwijs, de categorie 'geen diploma' is de referentiecategorie. Het maandelijks gezinsinkomen werd gemeten aan de hand van vijftien categorieën. De categorie 'zeg ik liever niet' werd als missing gecodeerd $(\mathrm{n}=127)$. Aan de hand van visual binning ${ }^{1}$ op basis van de kwartielen werd de variabele individueel sociaal kapitaal gecodeerd naar vier categorieën. De kenmerken omtrent onlinegedrag en kennis zijn de volgende. Internetgebruik werd geoperationaliseerd door te vragen aan de respondenten hoe vaak zij het internet gebruiken (negenpuntenschaal). De vertrouwdheid met artificiële intelligentie werd gemeten aan de hand van de mate waarin de respondent hier al van had gehoord (vierpuntenschaal). Het onlinegedrag werd geoperationaliseerd aan de hand van de mate waarin zij thuis of op het werk persoonlijke informatie delen op sociale-netwerksites (achtpuntenschaal).

Om de variabele angst voor criminaliteit te meten werd gekozen voor de gedragsmatig-expressieve dimensie, met name mijdgedrag, die werd geconstrueerd aan de hand van drie items. ${ }^{2}$ Mijdgedrag werd gemeten aan de hand van een vijfpunten-

1 Visual binning is een procedure waarbij nieuwe variabelen worden gecreëerd door bestaande continue variabelen te groeperen tot een beperkt aantal categorieën.

2 Namelijk: (1) Gebeurt het dat u bepaalde plekken mijdt omdat u het niet veilig vindt? (2) Gebeurt het dat $\mathrm{u}$ vermijdt om open te doen voor onbekenden omdat $\mathrm{u}$ het niet veilig vindt? (3) Gebeurt het dat u vermijdt om weg te gaan van huis als het donker is? 
schaal, Cronbachs $\alpha$ bedraagt 0,78 voor deze schaal. ${ }^{3}$ Een factoranalyse werd als test op unidimensionaliteit uitgevoerd, deze had één factor als resultaat, waardoor dus geconcludeerd kan worden dat de schaal unidimensioneel en intern consistent is.

De kenmerken van (gepercipieerde) onveiligheid zijn de volgende. Slachtofferschap is een dichotome variabele en werd gemeten aan de hand van het al dan niet zelf slachtoffer geweest zijn van één of meer strafbare feiten in de afgelopen vijf jaar. Direct slachtofferschap werd gecodeerd als één, geen slachtofferschap als nul. De variabele gepercipieerde overlast werd geconstrueerd aan de hand van de variabelen rond sociale overlast, ${ }^{4}$ Cronbachs $\alpha$ bedraagt 0,78 voor deze schaal. Na het uitvoeren van een factoranalyse kon unidimensionaliteit worden vastgesteld.

De perceptie van fake news op enerzijds traditionele media en anderzijds sociale media werd geoperationaliseerd door te vragen in welke mate de respondent van oordeel is dat fake news voorkomt. De mate van de gepercipieerde prevalentie van fake news werd gemeten aan de hand van een vijfpuntenschaal gaande van nooit tot zeer vaak. De respondenten kregen de volgende definitie als toelichting bij de twee vragen over de eigen perceptie: 'Fake news zijn valse of misleidende nieuwsberichten die op een niet-toevallige manier verspreid worden. Ze hebben als doel de publieke opinie te manipuleren en de doelgroep te misleiden.' De twee vragen luidden als volgt:

- Geef aan in welke mate u denkt dat fake news voorkomt op de traditionele nieuwsmedia (tv, radio, gedrukte media, nieuwssites op het internet).

- Geef aan in welke mate u denkt dat fake news voorkomt op de sociale media (bijv. Facebook, Twitter, Instagram).

\subsection{Analytische strategie}

Drie hiërarchische multivariate regressieanalyses werden uitgevoerd met behulp van SPSS (versie 26). Deze methode wordt gebruikt om theorietoetsende analyses te verrichten. Met een hiërarchische regressievergelijking kan een beeld gecreëerd worden van de toegevoegde waarde van het opnemen van onafhankelijke variabelen en zo kan nagegaan worden of deze toevoegingen leiden tot significante verbeteringen van het model.

\section{Resultaten}

Onderstaand worden de resultaten van de drie hiërarchische multivariate regressieanalyses telkens onder de bijhorende tabel besproken. Aan de assumpties lineariteit, homoscedasticiteit en normaliteit werd driemaal voldaan, tevens was er

3 Dit is een maat voor interne consistentie van items. De vuistregel die in onderzoek gehanteerd wordt, is een minimumwaarde van 0,80 . In de praktijk wordt een waarde van 0,70 doorgaans ook geaccepteerd. Factorladingen en Cronbachs $\alpha$ van de schaalconstructen in deze studie zijn terug te vinden in tabel 4 in de appendix.

4 Namelijk: (1) Een groepje valt iemand lastig op straat om geld of andere zaken te verkrijgen. (2) Een paar mannen drinken alcohol op straat. (3) Iemand verkoopt drugs op straat. (4) Jongeren vechten op straat. 
Tabel 1 Resultaten hiërarchische regressieanalyse voor angst voor criminaliteit (mijdgedrag)

\begin{tabular}{llllll}
\hline Onafhankelijke & Model I & Model 2 & Model 3 & Model 4 & Model 5 \\
variabelen & Bèta-waar- & Bèta-waar- & Bèta-waar- & Bèta-waar- & Bèta-waar- \\
& den & den & den & den & den
\end{tabular}

Individuele kwetsbaarheid

Socio-demografische kenmerken

\begin{tabular}{|c|c|c|c|c|c|}
\hline $\begin{array}{l}\text { Geslacht } \\
(\text { referentie = man })\end{array}$ & $0,348^{\star * *}$ & $0,354^{\star \star *}$ & $0,353^{\star * *}$ & $0,352^{\star \star *}$ & $0,353^{\star \star \star}$ \\
\hline $\begin{array}{l}\text { Nationaliteit } \\
(\text { referentie = Belg) }\end{array}$ & $-0,010$ & $-0,017$ & $-0,024$ & $-0,024$ & $-0,025$ \\
\hline $\begin{array}{l}\text { Alleenstaand } \\
\text { (referentie = } \\
\text { niet-alleenstaand) }\end{array}$ & $0,07 I^{*}$ & $-0,066^{\star *}$ & $-0,056^{*}$ & $-0,055^{\star}$ & $-0,052^{\star}$ \\
\hline $\begin{array}{l}\text { Leeftijd } \\
25-34 \text { jaar } \\
35-44 \text { jaar } \\
45-54 \text { jaar } \\
55-64 \text { jaar } \\
\geq 65 \text { jaar } \\
\text { (referentie = } 18-24 \\
\text { jaar) }\end{array}$ & $\begin{array}{l}-0,013 \\
-0,028 \\
-0,005 \\
0,050 \\
0,163^{\star \star \star}\end{array}$ & $\begin{array}{l}-0,018 \\
-0,038 \\
-0,016 \\
0,039 \\
0,153^{\star \star \star}\end{array}$ & $\begin{array}{l}-0,024 \\
-0,040 \\
-0,014 \\
0,043 \\
0,175^{\star \star \star}\end{array}$ & $\begin{array}{l}-0,022 \\
-0,038 \\
-0,013 \\
0,046 \\
0,179 * \star \star\end{array}$ & $\begin{array}{l}-0,026 \\
-0,043 \\
-0,017 \\
0,039 \\
0,165^{\star \star \star}\end{array}$ \\
\hline \multicolumn{6}{|c|}{ Socio-economische kenmerken } \\
\hline Inkomen & $-0,080^{\star *}$ & $-0,074^{\star \star}$ & $0,064^{\star *}$ & $-0,063^{\star *}$ & $-0,060^{\star}$ \\
\hline $\begin{array}{l}\text { Diploma } \\
\text { geen } \\
\text { lager ond./lager sec. } \\
\text { sec. ond. } \\
\text { (referentie = hoger } \\
\text { onderwijs) }\end{array}$ & $\begin{array}{l}0,045 \\
0,068^{\star \star} \\
0,089^{\star \star}\end{array}$ & $\begin{array}{l}0,035 \\
0,059^{\star} \\
0,75^{\star \star}\end{array}$ & $\begin{array}{l}0,033 \\
0,051^{\star} \\
0,074^{\star \star}\end{array}$ & $\begin{array}{l}0,033 \\
0,050^{\star} \\
0,071^{\star *}\end{array}$ & $\begin{array}{l}0,028 \\
0,046 \\
0,069^{\star \star}\end{array}$ \\
\hline $\begin{array}{l}\text { Sociaal kapitaal } \\
\text { (Gepercipieerde) on }\end{array}$ & - & $-0,094^{\star \star \star}$ & $-0,104^{\star \star \star}$ & $-0,103^{\star \star \star}$ & $-0,099^{\star \star \star}$ \\
\hline $\begin{array}{l}\text { Slachtofferschap } \\
\text { (referentie = nee) }\end{array}$ & - & - & $-0,020$ & $-0,021$ & $-0,017$ \\
\hline $\begin{array}{l}\text { Gepercipieerde } \\
\text { overlast }\end{array}$ & - & - & $0,145^{\star \star \star}$ & $0,142^{\star \star \star}$ & $0,144^{\star \star \star}$ \\
\hline $\begin{array}{l}\text { Fake news op trad. } \\
\text { media }\end{array}$ & - & - & - & 0,035 & $0,060^{*}$ \\
\hline $\begin{array}{l}\text { Fake news op soc. } \\
\text { media }\end{array}$ & - & - & - & - & $-0,058^{\star}$ \\
\hline Adjusted $\mathbf{R}^{2}$ & 0,210 & 0,217 & 0,236 & 0,237 & 0,239 \\
\hline Veranderingen in $\mathbf{R}^{2}$ & - & $\star \star \star$ & $\star \star \star *$ & - & * \\
\hline
\end{tabular}

${ }^{*}=p<0,05 ;{ }^{* *}=p<0,01 ;{ }^{* * *}=p<0,001$ 
geen sprake van multicollineariteit..$^{5}$ In tabel 5 tot en met 12 in de appendix zijn de univariate statistieken terug te vinden van de in dit onderzoek gebruikte concepten. De correlaties tussen de verschillende concepten zijn terug te vinden in tabel 13 in de appendix.

In de eerste analyse (zie tabel 1) werd nagegaan in welke mate individuele kwetsbaarheid, (gepercipieerde) onveiligheid en de gepercipieerde prevalentie van fake news op respectievelijk traditionele nieuwsmedia en sociale media een effect hebben op mijdgedrag. ${ }^{6}$ De analyse werd stapsgewijs opgebouwd, waarbij steeds nieuwe (blokken van) variabelen werden toegevoegd aan het model. Gegeven het feit dat de effectgroottes en significantiewaarden niet substantieel wijzigen over de verschillende modellen heen, zullen uitsluitend de resultaten van het finale model (5) beschreven worden.

Uit de resultaten kan afgeleid worden dat vrouwen, alleenstaanden, 65-plussers, personen met een lager netto-gezinsinkomen en een lager opleidingsniveau meer mijdgedrag rapporteren. Er wordt geen significant effect voor nationaliteit vastgesteld. Personen die aangeven over minder individueel sociaal kapitaal te beschikken, rapporteren meer mijdgedrag. Hierbij dient opgemerkt te worden dat uitsluitend de effecten van geslacht, leeftijd en individueel sociaal kapitaal als relevant beschouwd kunnen worden (Bèta $\geq 0,1$ ). Individuele kwetsbaarheid speelt dus een belangrijke rol bij mijdgedrag.

De effecten van (gepercipieerde) onveiligheid zijn niet eenduidig. Voorgaand slachtofferschap blijkt niet geassocieerd te zijn met de mate waarin men aangeeft mijdgedrag te vertonen. Wel blijkt er een positieve relatie te bestaan tussen gepercipieerde overlast en mijdgedrag: hoe meer overlast men percipieert, hoe meer mijdgedrag men rapporteert. Daarnaast onderstreept deze vaststelling de complexe en niet-monocausale relatie tussen criminaliteit/slachtofferschap en angst voor criminaliteit.

Wanneer gekeken wordt naar de variabelen voor de perceptie van fake news, wordt een niet eenduidig verband vastgesteld. Personen die aangeven meer fake news waar te nemen op traditionele media, rapporteren meer mijdgedrag. Daarentegen blijkt dat personen die aangeven meer fake news waar te nemen op sociale media minder mijdgedrag rapporteren. Er dient hierbij opgemerkt te worden dat beide effecten klein zijn (Bèta < 0,1) en bijgevolg inhoudelijk niet als relevant beschouwd kunnen worden. De introductie van deze twee variabelen in het finale model hebben wel een significante verbetering van de proportie verklaarde variantie ${ }^{7}$ tot ge-

5 Aan de hand van de Cook's en Leverage-waarde kon vastgesteld worden dat er outliers aanwezig waren. Deze analyses werden daarom ook uitgevoerd zonder outliers. Daaruit bleek dat de verschillen in de analyses met of zonder outliers niet groot waren en de tendensen hetzelfde. Om deze reden werden de outliers opgenomen in de gepresenteerde analyse.

6 Het effect wordt afgeleid uit de Bèta-waarde en kan geïnterpreteerd worden zoals correlatiecoëfficiënten. De Bèta-waarden indiceren het relatieve belang van de onafhankelijke variabelen en laten zo een vergelijking tussen de effecten van de onafhankelijke variabelen toe. Een Bèta-waarde wordt als inhoudelijk relevant beschouwd vanaf de minimumwaarde 0,1 .

$7 \quad \mathrm{R}^{2}$ is de determinatiecoëfficiënt en geeft het percentage verklaarde variantie in de afhankelijke variabele door de onafhankelijke variabele(n) weer. In de analyses wordt gebruikgemaakt van de adjusted $\mathrm{R}^{2}$, omdat dit een meer kritische maat is, aangezien er rekening wordt gehouden met het aantal onafhankelijke variabelen. 
volg. In het finale model zijn de onafhankelijke variabelen verantwoordelijk voor 23,9\% van de variantie in de afhankelijke variabele (mijdgedrag).

Tabel 2 Resultaten hiërarchische regressieanalyse voor perceptie fake news op traditionele media

\begin{tabular}{|c|c|c|c|}
\hline Onafhankelijke variabelen & $\begin{array}{l}\text { Model I } \\
\text { Bèta-waarden }\end{array}$ & $\begin{array}{l}\text { Model } 2 \\
\text { Bèta-waarden }\end{array}$ & $\begin{array}{l}\text { Model } 3 \\
\text { Bèta-waarden }\end{array}$ \\
\hline \multicolumn{4}{|c|}{ Socio-demografische kenmerken } \\
\hline $\begin{array}{l}\text { Geslacht } \\
\text { (referentie = man) }\end{array}$ & 0,040 & 0,052 & 0,015 \\
\hline $\begin{array}{l}\text { Nationaliteit } \\
\text { (referentie = Belg) }\end{array}$ & 0,002 & 0,001 & 0,006 \\
\hline $\begin{array}{l}\text { Alleenstaand } \\
\text { (referentie = nee) }\end{array}$ & 0,029 & 0,029 & $0,054^{\star}$ \\
\hline $\begin{array}{l}\text { Leeftijd } \\
25-34 \text { jaar } \\
35-44 \text { jaar } \\
45-54 \text { jaar } \\
55-64 \text { jaar } \\
\geq 65 \text { jaar } \\
\text { (referentie = 18-24 jaar) }\end{array}$ & $\begin{array}{l}-0,048 \\
-0,061 \\
-0,022 \\
-0,085^{\star} \\
-0,123^{\star *}\end{array}$ & $\begin{array}{l}-0,039 \\
-0,048 \\
-0,001 \\
-0,052 \\
-0,065\end{array}$ & $\begin{array}{l}-0,008 \\
-0,003 \\
0,021 \\
-0,015 \\
0,020\end{array}$ \\
\hline \multicolumn{4}{|l|}{ Socio-economische kenmerken } \\
\hline Inkomen & $-0,010$ & $-0,024$ & $-0,036$ \\
\hline $\begin{array}{l}\text { Diploma } \\
\text { geen } \\
\text { lager ond./lager sec. } \\
\text { sec. ond. } \\
\text { (referentie = hoger onderwijs) }\end{array}$ & $\begin{array}{l}0,002 \\
0,039 \\
0,066^{\star}\end{array}$ & $\begin{array}{l}0,019 \\
0,058^{\star} \\
0,084^{\star \star}\end{array}$ & $\begin{array}{l}0,040 \\
0,061^{\star} \\
0,073^{\star \star}\end{array}$ \\
\hline \multicolumn{4}{|l|}{ Onlinegedrag en kennis } \\
\hline Onlinegedrag & - & 0,020 & $-0,013$ \\
\hline A.I. & - & 0,036 & $-0,037$ \\
\hline Internetgebruik & - & 0,069 & 0,017 \\
\hline Fake news op soc. media & - & - & $0,467^{\star \star \star}$ \\
\hline Adjusted $\mathbf{R}^{2}$ & 0,009 & 0,012 & 0,205 \\
\hline Veranderingen in $\mathbf{R}^{\mathbf{2}}$ & - & - & 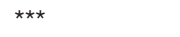 \\
\hline
\end{tabular}

${ }^{*}=p<0,05 ;{ }^{* *}=p<0,01 ;{ }^{* * *}=p<0,001$

In tabel 2 worden de resultaten van de analyse met de gepercipieerde prevalentie van fake news op traditionele nieuwsmedia als afhankelijke variabele weergegeven. Op basis van het eerste model kan worden afgeleid dat socio-demografische en -economische kenmerken, die werden opgenomen als controlevariabelen, een minimaal effect hebben op de gepercipieerde prevalentie van fake news op traditionele media. Er wordt een klein effect voor leeftijd vastgesteld, waarbij ouderen aangeven minder fake news waar te nemen op traditionele media dan jongeren.

In het tweede model werden de kenmerken omtrent onlinegedrag en kennis toegevoegd. Hieruit blijkt dat deze geen significant effect hebben op de gepercipieerde prevalentie van fake news op traditionele nieuwsmedia. Vervolgens werd in model 3 de gepercipieerde prevalentie van fake news op sociale media als onafhankelijke 
variabele opgenomen. De gepercipieerde prevalentie van fake news op sociale media heeft een significant positief en substantieel effect. Dit houdt in dat personen die aangeven meer fake news waar te nemen op sociale media, ook meer fake news waarnemen op traditionele nieuwsmedia.

Tabel 3 Resultaten hiërarchische regressieanalyse voor perceptie fake news op sociale media

\begin{tabular}{|c|c|c|c|}
\hline Onafhankelijke variabelen & $\begin{array}{l}\text { Model I } \\
\text { Bèta-waarden }\end{array}$ & $\begin{array}{l}\text { Model } 2 \\
\text { Bèta-waarden }\end{array}$ & $\begin{array}{l}\text { Model } 3 \\
\text { Bèta-waarden }\end{array}$ \\
\hline \multicolumn{4}{|c|}{ Socio-demografische kenmerken } \\
\hline $\begin{array}{l}\text { Geslacht } \\
\text { (referentie = man) }\end{array}$ & 0,039 & $0,081^{\star \star}$ & $0,059^{\star}$ \\
\hline $\begin{array}{l}\text { Nationaliteit } \\
\text { (referentie = Belg) }\end{array}$ & $-0,018$ & $-0,012$ & $-0,012$ \\
\hline $\begin{array}{l}\text { Alleenstaand } \\
(\text { referentie = nee })\end{array}$ & $-0,049$ & $-0,052$ & $-0,064^{\star \star}$ \\
\hline $\begin{array}{l}\text { Leeftijd } \\
25-34 \text { jaar } \\
35-44 \text { jaar } \\
45-54 \text { jaar } \\
55-64 \text { jaar } \\
\geq 65 \text { jaar }\end{array}$ & $\begin{array}{l}-0,088^{\star} \\
-0,126^{\star \star} \\
-0,097^{\star} \\
-0,158^{\star \star \star} \\
-0,\left.31\right|^{\star \star \star}\end{array}$ & $\begin{array}{l}-0,066 \\
-0,097^{\star} \\
-0,046 \\
-0,078 \\
-0,182^{\star \star \star}\end{array}$ & $\begin{array}{l}-0,050 \\
-0,077^{\star} \\
-0,046 \\
-0,056 \\
-0,154^{\star \star \star}\end{array}$ \\
\hline \multicolumn{4}{|l|}{ (referentie = 18-24 jaar $)$} \\
\hline \multicolumn{4}{|c|}{ Socio-economische kenmerken } \\
\hline Inkomen & $0,064^{\star}$ & 0,025 & 0,035 \\
\hline $\begin{array}{l}\text { Diploma } \\
\text { geen } \\
\text { lager ond./lager sec. } \\
\text { sec. ond. }\end{array}$ & $\begin{array}{l}-0,091^{\star \star} \\
-0,060^{\star} \\
-0,031\end{array}$ & $\begin{array}{l}-0,045 \\
-0,006 \\
0,022\end{array}$ & $\begin{array}{l}-0,053^{*} \\
-0,031 \\
-0,013\end{array}$ \\
\hline \multicolumn{4}{|l|}{ (referentie = hoger onderwijs) } \\
\hline \multicolumn{4}{|l|}{ Onlinegedrag en kennis } \\
\hline Onlinegedrag & - & $0,069^{\star *}$ & $0,061^{\star \star}$ \\
\hline A.I. & - & $0,157^{\star \star \star}$ & $0,142^{\star \star \star}$ \\
\hline Internetgebruik & - & $0, I I I^{\star \star}$ & $0,082^{\star *}$ \\
\hline Fake news op trad. media & - & - & $0,419^{\star * \star}$ \\
\hline Adjusted $\mathbf{R}^{2}$ & 0,080 & 0,114 & 0,287 \\
\hline Veranderingen in $\mathbf{R}^{2}$ & - & *** & $\star \star \star \star$ \\
\hline
\end{tabular}

${ }^{*}=p<0,05 ;{ }^{* *}=p<0,01 ;{ }^{* \star *}=p<0,001$

In tabel 3 worden de resultaten van de analyse met de gepercipieerde prevalentie van fake news op sociale media als afhankelijke variabele weergegeven. In vergelijking met de voorgaande analyse worden meer uitgesproken verbanden vastgesteld met de socio-demografische en -economische kenmerken. Dit geldt hoofdzakelijk voor leeftijd en opleidingsniveau: personen met een hogere leeftijd of met een lager opleidingsniveau geven aan minder fake news waar te nemen op sociale media. Daarnaast wordt voor het netto gezinsinkomen een klein significant effect vastge- 
steld: personen met een hoger netto gezinsinkomen geven aan meer fake news waar te nemen op sociale media.

In het tweede model worden de variabelen omtrent onlinegedrag en kennis toegevoegd. Deze variabelen hebben alle drie een significant positief effect op de gepercipieerde prevalentie van fake news op sociale media. Personen die frequent onlineactiviteiten uitvoeren, meer kennis hebben over artificiële intelligentie (AI) en meer tijd op het internet doorbrengen, geven vaker aan fake news waar te nemen via sociale media. Tot slot blijkt ook gepercipieerde prevalentie van fake news op traditionele media een significant positief effect te hebben op de gepercipieerde prevalentie van fake news op sociale media.

\section{Discussie en conclusie}

Uit voorgaand wetenschappelijk onderzoek (bijv. Ditton et al., 2004; Näsi et al., 2021) blijkt dat media een substantiële rol spelen in het ontstaan en onderhouden van angst voor criminaliteit. Op basis van onze studie kunnen we besluiten dat er een relatie bestaat tussen de gepercipieerde prevalentie van fake news en mijdgedrag, al gaat het niet om een sterke relatie. Er wordt vastgesteld dat andere relevante variabelen die in deze studie werden opgenomen (onder andere geslacht, leeftijd, sociaal kapitaal en gepercipieerde overlast) belangrijker zijn. Wanneer gekeken wordt naar de modellen waarbij de perceptie van fake news als afhankelijke variabele wordt beschouwd, valt op dat er sterke overlap is tussen de perceptie van fake news op traditionele media en die op sociale media, maar dat er tegelijkertijd belangrijke verschillen zijn. Zo hebben onlinegedrag en kennis, alsook leeftijd, een significant effect op de perceptie van fake news op sociale media, maar niet op de perceptie van fake news in traditionele media.

Er werd in deze studie gekozen om de percepties van het voorkomen van fake news te bestuderen, aangezien voorgaand onderzoek reeds heeft aangetoond dat media een (grotere) rol spelen wanneer er sprake is van eigen belangstelling en interpretaties van criminaliteitgerelateerde mediaberichten. Zo is het aannemelijk te veronderstellen dat ook de relatie tussen fake news en angst voor criminaliteit zal variëren naargelang de gepercipieerde inhoud.

Deze bijdrage kan beschouwd worden als een eerste verkennende en representatieve studie naar de relatie tussen fake news en angst voor criminaliteit (meer specifiek: mijdgedrag). We zijn daarbij niet blind voor een aantal beperkingen. Een eerste beperking is dat uit de antwoorden op de twee vragen rond de gepercipieerde prevalentie van fake news niet kan afgeleid worden hoe de respondent het fenomeen zelf invult en herkent, hoeveel hij of zij al daadwerkelijk (bewust of onbewust) in aanraking is gekomen met fake news, hoeveel mediabronnen hij of zij raadpleegt waar fakenewsberichten op verschijnen of hoe de respondent de mogelijke effecten van fake news ervaart. Een tweede beperking heeft te maken met de operationalisering van angst voor criminaliteit. Door angst voor criminaliteit te operationaliseren als mijdgedrag werd louter de gedragsmatig-expressieve dimensie onderzocht. Een derde beperking is dat in de analyses van deze bijdrage de focus uitsluitend op het individuele niveau lag. Individuele determinanten van angst voor criminaliteit staan echter niet volledig los van contextuele determinanten 
(zoals kenmerken van de woonbuurt). Een belangrijke en laatste beperking heeft te maken met het cross-sectioneel design van deze studie. De gevonden effecten en verbanden kunnen dus evengoed in de andere richting worden geïnterpreteerd, dat is meteen ook de reden waarom we steeds spreken over relaties en niet in termen van causaliteit.

Ondanks deze beperkingen heeft deze studie ons toch in staat gesteld een aantal eerste relaties bloot te leggen, en vooral ook ideeën aangereikt voor verder onderzoek. Een eerste suggestie voor vervolgonderzoek heeft te maken met de meting van het concept fake news. We pleiten voor een theoretisch gefundeerde operationalisering, een geschikte meetmethode en een gepaste analytische strategie. Hier liggen mogelijkheden tot het opzetten van interdisciplinaire samenwerking, bijvoorbeeld met communicatie- en mediawetenschappen. Aangezien fake news een fenomeen is dat diverse verschijningsvormen via diverse kanalen behelst, is het aangewezen om zowel aandacht te besteden aan de inhoud als de vorm van het concept. Een survey aangevuld met situatieschetsen en/of concrete voorbeelden van fakenewsberichten (bijv. in de vorm van een factorial survey experiment, zie De Buck \& Pauwels, 2020) zou een geschikt meetinstrument kunnen opleveren. Ten tweede is het ook relevant om te kijken naar de invulling en meting van het concept angst voor criminaliteit zelf. De conceptualisering van dit begrip, zoals opgenomen in deze studie, dateert van voor de introductie van het internet en sociale media, en bijgevolg kan de vraag gesteld worden of ze nog beantwoordt aan deze hedendaagse ontwikkelingen. Ten derde kan het ook waardevol zijn dat er naast het effect op angst voor criminaliteit ook wordt ingegaan op de mogelijke andere effecten die fake news kan hebben op het individu. Deze mogelijke effecten kunnen bijvoorbeeld veranderingen in gedrag, denkwijze, ideologie, politieke voorkeur of wereldbeeld inhouden, die indirecte repercussies hebben voor angst voor criminaliteit en daaraan gerelateerde gedragingen. Ten vierde zouden we ook willen aanbevelen om in toekomstig onderzoek rekening te houden met de context (bijv. de woonbuurt, school- en werkcontext, gezinscontext), omdat voorgaand onderzoek frequent heeft aangetoond dat contextuele kenmerken de individuele angst voor criminaliteit (in)direct beïnvloeden (Hardyns et al., 2019b). Als vijfde en laatste suggestie kan het interessant zijn om te kijken naar de mogelijke effecten die fake news kan hebben op het beleid en daarbij een vergelijking te maken tussen beleid dat reeds gevoerd wordt en welke initiatieven betrokken stakeholders nemen om de verspreiding en gevolgen van fake news tegen te gaan. Daarnaast kan het ook interessant zijn om te kijken naar wat van de media zelf kan verwacht worden en welk beleid zij reeds voeren om de problematiek van fake news tegen te gaan. De impact van fake news op (veiligheid in) de samenleving is de laatste jaren steeds groter en duidelijker geworden. Een reden te meer om dit thema hoog op de academische agenda te plaatsen.

\section{Literatuur}

Adriaenssen, A. (2016) Publieke ernstpercepties van criminaliteit en het verband met televisiegebruik: Een kwantitatieve studie bij de Vlaamse bevolking. Den Haag: Boom Uitgevers.

Burkhardt, J.M. (2017) History of fake news. Library Technology Reports, 53(8), 5-9. 
Centraal Bureau voor de Statistiek (2020) Veiligheidsmonitor 2019. www.cbs.nl/nl-nl/ publicatie/2020/10/veiligheidsmonitor-2019.

Chiricos, T., S. Eschholz \& M. Gertz (1997) Crime, news and fear of crime: Toward an identification of audience effects. Social Problems, 44(3), 342-357.

Chiricos, T., K. Padgett \& M. Gertz (2000) Fear, TV news, and the reality of crime. Criminology, 38(3), 755-786.

Cossman, J.S. \& N.E. Rader (2011) Fear of crime and personal vulnerability: Examining self-reported health. Sociological Spectrum, 31(2), 141-162.

Cunha, E., G. Magno, J. Caetano, D. Teixeira \& V. Almeida (2018) Fake news as we feel it: Perception and conceptualization of the term 'fake news' in the media. In: S. Staab, O. Koltsova \& D. Ignatov (eds.), Social Informatics. SocInfo 2018 (p. 151-166) Springer. doi.org/10.1007/978-3-030-01129-1_10.

De Buck, A. \& L. Pauwels (2020) Het factorial survey experiment in criminologisch onderzoek. In: W. Hardyns \& T. Snaphaan (eds.), Big data en innovatieve methoden voor criminologisch onderzoek (p. 237-265). Den Haag: Boom criminologie.

De Groof, S. (2006) Het (on)grijpbare onveiligheidsgevoel: Een exploratie van de structuur binnen het onveiligheidsconcept van mannen en vrouwen. Tijdschrift voor Criminologie, 48(1), 19-34.

Ditton, J. \& S. Farrall (2000) The fear on crime. Farnham: Ashgate.

Ditton, J., D. Chadee, S. Farrall, E. Gilchrist \& J. Bannister (2004) From imitation to intimidation: A note on the curious and changing relationship between the media, crime and fear of crime. British Journal of Criminology, 44(4), 595-610.

Elffers, H. \& W. de Jong (2004) Nee, ik voel me nooit onveilig: Determinanten van sociale veiligheidsgevoelens. Raad voor Maatschappelijke Ontwikkeling.

Farrall, S., J. Jackson \& E. Gray (2009) Social order and the fear of crime in contemporary times. Oxford: Oxford University Press.

Ferguson, K.M. \& C.H. Mindel (2007) Modeling fear of crime in Dallas neighborhoods: A test of social capital theory. Crime \& Delinquency, 53(2), 322-349.

Gainey, R., M. Alper \& A.T. Chappell (2011) Fear of crime revisited: Examining the direct and indirect effects of disorder, risk perception, and social capital. American Journal of Criminal Justice, 36(2), 120-137.

Gerbner, G. \& L. Gross (1976) Living with television: The violence profile. Journal of Communication, 26(2), 172-199.

Hale, C. (1996) Fear of crime: A review of the literature. International Review of Victimology, 4(2), 79-150.

Hardyns, W. \& L. Pauwels (2010) Different measures of fear of crime and survey measurement error. In: M. Cools, B. De Ruyver, M. Easton, L. Pauwels, P. Ponsaers, G. Vande Walle, T. Vander Beken, F. Vander Laenen, G. Vermeulen, \& G. Vynckier (eds.), Safety, societal problems and citizens' perceptions: New empirical data, theories and analyses. (Vol. 3, p. 19-39). Antwerpen: Maklu.

Hardyns, W. \& L. Pauwels (2014) De relatie tussen economische achtergesteldheid en onveiligheidsbeleving: Een Gentse buurtanalyse. In: L. Pauwels, S. De Keulenaer, S. Deltenre, E. Devroe, J. Forceville, W. Hardyns, R. Kerkab, E. Maes, D. Moons, J. Plessers, S. Pleysier, P. Ponsaers, E. Van Dael, \& A. Verhage (eds.), Criminografische ontwikkelingen III: Van (victim-)survey tot penitentiaire statistiek (Vol. 9, p. 51-75). Antwerpen: Maklu.

Hardyns, W., K. Ponnet, L. Pauwels, M. Walrave, L. Kimpe \& T. Snaphaan (2019a) Social Capital in Neighborhoods (SCAN): Een interdisciplinaire studie over online en offline sociaal kapitaal en risicogedrag. Panopticon, 40(3), 223-235.

Hardyns, W., T. Snaphaan, L.J.R. Pauwels, V. Vyncke \& S. Willems (2019b) A multilevel analysis of collective efficacy, neighborhood disorder, and individual social capital on avoidance behavior. Crime \& Delinquency, 65(7), 994-1021. 
Hendriks, L.H. (2019) Influence of a fake news message on fear of crime (bachelorproef, Universiteit Twente). https://essay.utwente.nl/78238.

Hirsch, P.M. (1980) The 'scary world' of the nonviewer and other anomalies: A reanalysis of Gerbner et al.'s findings on cultivation analysis part I. Communication Research, 7(4), 403-456.

Hirsch, P.M. (1981) On not learning from one's mistakes: A reanalysis of Gerbner et ally's findings on cultivation analysis part II. Communication Research, 8(1), 3-37.

Hughes, M. (1980). The fruits of cultivation analysis: A reexamination of some effects of television watching. Public Opinion Quarterly, 44(3), 287-302.

Intravia, J., K.T. Wolff, R. Paez \& B.R. Gibbs (2017) Investigating the relationship between social media consumption and fear of crime: A partial analysis of mostly young adults. Computers in Human Behavior, 77(1), 158-168.

Jaster, R. \& D. Lanius (2018) What is fake news? Versus, 47(2), 207-224.

Lane, J. \& J.W. Meeker (2003) Ethnicity, information sources, and fear of crime. Deviant Behavior, 24(1), 1-26.

Lazer, D.M., M.A. Baum, Y. Benkler, A.J. Berinsky, K.M. Greenhill, F. Menczer \& M. Schudson (2018) The science of fake news. Science, 359(6380), 1094-1096.

Lee, M. (2007) Inventing fear of crime: Criminology and the politics of anxiety. London: Willan Publishing.

Lembrechts, L. (2007) Het onveiligheidsgevoel als media-effect. Inspiratie voor een theoretisch model. Tijdschrift voor Criminologie, 49(3), 277-290.

Näsi, M., M. Tanskanen, J. Kivivuori, P. Haara \& E. Reunanen (2021) Crime news consumption and fear of violence: The role of traditional media, social media, and alternative information sources. Crime \& Delinquency, 67(4), 574-600 doi. org/10.1177/0011128720922539.

Pleysier, S. (2009) 'Angst voor criminaliteit' onderzocht. De brede schemerzone tussen alledaagse realiteit en irrationeel fantoom (diss. KU Leuven). https://lirias.kuleuven.be/ retrieve/69265.

Shu, K., A. Sliva, S. Wang, J. Tang \& H. Liu (2017) Fake news detection on social media: A data mining perspective. ACM SIGKDD Explorations Newsletter, 19(1), 22-36.

Taylor, R. \& M. Hale (1986) Testing alternative models of fear of crime. The Journal of Criminal Law \& Criminology, 77(1), 151-189.

Vanderveen, G. (2006) Interpreting fear, crime, risk and unsafety: Conceptualisation and measurement. Den Haag: Boom Juridische uitgevers.

Verheyden, T. (2020, 28 februari) Check: Dit WhatsApp-bericht met valse informatie over het coronavirus is géén bericht van Volksgezondheid. VRT NWS. www.vrt.be/vrtnws/ nl/2020/02/28/dit-bericht-met-valse-informatie-over-het-coronavirus-is-geen-of.

Wyant, B.R. (2008) Multilevel impacts of perceived incivilities and perceptions of crime risk on fear of crime: Isolating endogenous impacts. Journal of Research in Crime and Delinquency, 45(1), 39-64. 


\section{Appendix}

Tabel 4 Operationalisering van angst voor criminaliteit en gepercipieerde overlast

\begin{tabular}{|c|c|c|}
\hline Schaalconstruct & Gebruikte items & Cronbachs $\alpha$ \\
\hline \multirow[t]{5}{*}{ Mijdgedrag } & $\begin{array}{l}\text { Vijfpuntenschaal voor elk item } \\
(\mid=\text { nooit, } 2=\text { zelden, } 3=\text { soms, } 4= \\
\text { vaak, } 5=\text { zeer vaak })\end{array}$ & 0,784 \\
\hline & & Factorladingen \\
\hline & $\begin{array}{l}\text { Gebeurt het dat u bepaalde plekken } \\
\text { mijdt omdat u het niet veilig vindt? }\end{array}$ & 0,813 \\
\hline & $\begin{array}{l}\text { Gebeurt het dat u vermijdt om open } \\
\text { te doen voor onbekenden omdat u } \\
\text { het niet veilig vindt? }\end{array}$ & 0,712 \\
\hline & $\begin{array}{l}\text { Gebeurt het dat u vermijdt om weg } \\
\text { te gaan van huis als het donker is? }\end{array}$ & 0,699 \\
\hline Schaalconstruct & Gebruikte items & Cronbachs $\alpha$ \\
\hline \multirow[t]{6}{*}{$\begin{array}{l}\text { Gepercipieerde } \\
\text { overlast }\end{array}$} & $\begin{array}{l}\text { Vijfpuntenschaal voor elk item } \\
(\mid=\text { nooit, } 2=\text { zelden, } 3=\text { soms, } 4= \\
\text { vaak, } 5=\text { zeer vaak })\end{array}$ & 0,782 \\
\hline & & Factorladingen \\
\hline & $\begin{array}{l}\text { Een groepje valt iemand lastig op } \\
\text { straat om geld of andere zaken te } \\
\text { verkrijgen. }\end{array}$ & 0,754 \\
\hline & $\begin{array}{l}\text { Een paar mannen drinken alcohol } \\
\text { op straat. }\end{array}$ & 0,722 \\
\hline & lemand verkoopt drugs op straat. & 0,701 \\
\hline & Jongeren vechten op straat. & 0,674 \\
\hline
\end{tabular}

Tabel 5 Univariate beschrijvende statistieken - Socio-demografische kenmer$\operatorname{ken}(n=1566)$

\begin{tabular}{lll}
\hline Variabelen / categorieën & Aantal & Percentage \\
\hline Geslacht & & \\
Man & 765 & $48,9 \%$ \\
Vrouw & 801 & $51,1 \%$ \\
Leeftijd & & \\
I8-24 jaar & 157 & $10,0 \%$ \\
$25-34$ jaar & 313 & $20,0 \%$ \\
$35-44$ jaar & 274 & $17,5 \%$ \\
$45-54$ jaar & 228 & $14,6 \%$ \\
$55-64$ jaar & 226 & $14,4 \%$ \\
$\geq 65$ jaar & 368 & $23,5 \%$ \\
Nationaliteit & & \\
Als Belg geboren & 1388 & $88,6 \%$ \\
Niet als Belg geboren & 178 & $11,4 \%$
\end{tabular}


Tabel 5 (Vervolg)

\begin{tabular}{lll}
\hline Variabelen / categorieën & Aantal & Percentage \\
\hline Alleenstaand & & \\
$\mathrm{Ja}$ & 436 & $27,8 \%$ \\
$\mathrm{Nee}$ & 1130 & $72,2 \%$ \\
\hline
\end{tabular}

Tabel 6 Univariate beschrijvende statistieken - Socio-economische kenmerken $(n=1566$, tenzij anders vermeld $)$

\begin{tabular}{lll}
\hline Variabelen / categorieën & Aantal & Percentage \\
\hline Hoogst behaalde opleiding & & \\
Geen & 53 & $3,4 \%$ \\
Lager onderwijs / lager secundair & 115 & $7,3 \%$ \\
Secundair onderwijs & 469 & $29,9 \%$ \\
Hoger onderwijs & 929 & $59,3 \%$ \\
Netto gezinsinkomen (EUR) (n = 1436; 127 missings) & & \\
(499,99 & 30 & $1,9 \%$ \\
$500,00-999,99$ & 63 & $4,0 \%$ \\
$1000,00-1499,99$ & 155 & $9,9 \%$ \\
$1500,00-1999,99$ & 172 & $11,0 \%$ \\
$2000,00-2499,99$ & 185 & $11,8 \%$ \\
$2500,00-2999,99$ & 136 & $8,7 \%$ \\
$3000,00-3499,99$ & 149 & $9,5 \%$ \\
$3500,00-3999,99$ & 128 & $8,2 \%$ \\
$4000,00-4499,99$ & 146 & $9,3 \%$ \\
$4500,00-4999,99$ & 78 & $5,0 \%$ \\
$5000,00-5499,99$ & 76 & $4,9 \%$ \\
$5500,00-5999,99$ & 42 & $2,7 \%$ \\
$6000,00-6499,99$ & 27 & $1,7 \%$ \\
$6500,00-6999,99$ & 13 & $0,8 \%$ \\
$\geq 7000,00$ & 39 & $2,5 \%$ \\
\hline
\end{tabular}

Tabel 7 Univariate beschrijvende statistieken - Individueel sociaal kapitaal (n = 1566)

\begin{tabular}{lll}
\hline Individueel sociaal kapitaal & Aantal & Percentage \\
\hline 0-3 personen & 396 & $25,3 \%$ \\
3-5 personen & 436 & $27,8 \%$ \\
5-10 personen & 519 & $33,1 \%$ \\
> 10 personen & 215 & $13,7 \%$ \\
\hline
\end{tabular}


Tabel 8 Univariate beschrijvende statistieken - Slachtofferschap $(n=1566)$

\begin{tabular}{lll}
\hline Slachtofferschap & Aantal & Percentage \\
\hline Wel slachtoffer & 352 & $22,5 \%$ \\
Niet slachtoffer & 1214 & $77,5 \%$ \\
\hline
\end{tabular}

Tabel 9 Univariate beschrijvende statistieken - Gepercipieerde overlast $(n=$ 1566)

\begin{tabular}{lcccccc}
\hline Variabele & Mean & Std & Min & Max & $\begin{array}{l}\text { Skew- } \\
\text { ness }\end{array}$ & $\begin{array}{l}\text { Kurto- } \\
\text { sis }\end{array}$ \\
\hline Gepercipieerde overlast & $\mathrm{I}, 78$ & 0,79 & $\mathrm{I}$ & 5 & $\mathrm{I}, 02$ & 0,50 \\
\hline
\end{tabular}

Tabel 10 Univariate beschrijvende statistieken - Onlinegedrag en kennis ( $n=$ 1566)

\begin{tabular}{|c|c|c|c|c|c|c|}
\hline Variabelen & Mean & Std & Min & Max & $\begin{array}{l}\text { Skew- } \\
\text { ness }\end{array}$ & $\begin{array}{l}\text { Kurto- } \\
\text { sis }\end{array}$ \\
\hline $\begin{array}{l}\text { Internetgebruik } \\
\text { (Nooit - maandelijks - I keer per } \\
\text { week; enkele dagen per week - elke } \\
\text { dag, ( I uur - elke dag, I tot } 2 \text { uur - } \\
\text { elke dag, } 2 \text { tot } 3 \text { uur - elke dag, } 3 \text { tot } \\
4 \text { uur - elke dag, > } 4 \text { uur) }\end{array}$ & 6,70 & 2,17 & I & 9 & $-1,06$ & 0,82 \\
\hline $\begin{array}{l}\text { Onlinegedrag } \\
\text { (Zelden of nooit - minder dan I keer } \\
\text { per maand - I keer per maand - } \\
\text { meerdere keren per maand, niet } \\
\text { wekelijks - I keer per week; } \\
\text { meerdere keren per week, niet } \\
\text { dagelijks - I keer per dag - meerde- } \\
\text { re keren per dag) }\end{array}$ & 2,40 & 1,93 & I & 8 & I,32 & 0,69 \\
\hline $\begin{array}{l}\text { Artificiële intelligentie } \\
\text { (Nee, nooit van gehoord - nee, maar } \\
\text { wel eens van gehoord - ja, ik ben er } \\
\text { een beetje bekend mee - ja, ik ben } \\
\text { ermee vertrouwd) }\end{array}$ & 2,53 & 1,06 & I & 4 & $-0,21$ & $-1,19$ \\
\hline
\end{tabular}

Tabel 11 Univariate beschrijvende statistieken - Mijdgedrag $(n=1566)$

\begin{tabular}{lllllll}
\hline Variabele & Mean & Std & Min & Max & $\begin{array}{l}\text { Skew- } \\
\text { ness }\end{array}$ & $\begin{array}{l}\text { Kurto- } \\
\text { sis }\end{array}$ \\
\hline Mijdgedrag & 2,18 & 0,94 & 1 & 5 & 0,80 & 0,13 \\
\hline
\end{tabular}


Birte Vandaele, Thom Snaphaan \& Wim Hardyns

Tabel 12 Univariate beschrijvende statistieken - Fake news ( $n=1566)$

\begin{tabular}{|c|c|c|c|c|c|c|}
\hline Variabelen & Mean & Std & Min & Max & $\begin{array}{l}\text { Skew- } \\
\text { ness }\end{array}$ & $\begin{array}{l}\text { Kurto- } \\
\text { sis }\end{array}$ \\
\hline $\begin{array}{l}\text { Fake news in traditionele media } \\
\text { (Nooit - zelden - soms - vaak - } \\
\text { zeer vaak) }\end{array}$ & 3,02 & 0,94 & I & 5 & 0,14 & $-0,35$ \\
\hline $\begin{array}{l}\text { Fake news in sociale media } \\
\text { (Nooit - zelden - soms - vaak - } \\
\text { zeer vaak) }\end{array}$ & $4, I I$ & 0,84 & I & 5 & $-1,01$ & $\mathrm{I}, 44$ \\
\hline
\end{tabular}


If it was shared on Facebook and Twitter, then it must be true

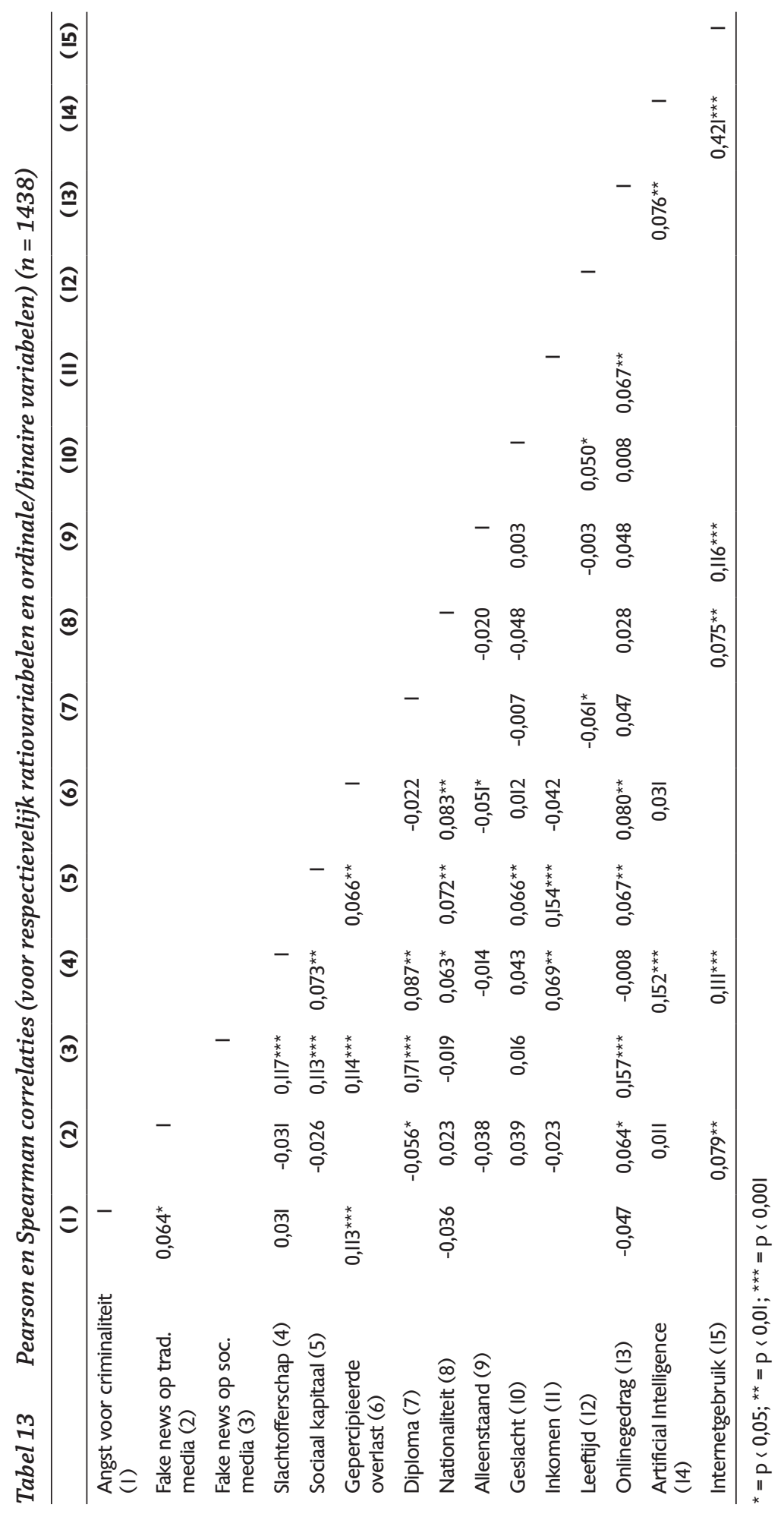

